\title{
How to Record Current Events like an Archaeologist
}

\author{
Matthew Magnani ๑, Anatolijs Venovcevs ๑, Stein Farstadvoll ๑, and \\ Natalia Magnani $\odot$
}

\section{ABSTRACT}

This article shows how to record current events from an archaeological perspective. With a case study from the COVID-19 pandemic in Norway, we provide accessible tools to document broad spatial and behavioral patterns through material culture as they emerge. Stressing the importance of ethical engagement with contemporary subjects, we adapt archaeological field methods-including geolocation, photography, and three-dimensional modeling-to analyze the changing relationships between materiality and human sociality through the crisis. Integrating data from four contributors, we suggest that this workflow may engage broader publics as anthropological data collectors to describe unexpected social phenomena. Contemporary archaeological perspectives, deployed in rapid response, provide alternative readings on the development of current events. In the presented case, we suggest that local ways of coping with the pandemic may be overshadowed by the materiality of large-scale corporate and state response.

Keywords: contemporary archaeology, COVID-19, archaeological survey, current events, photogrammetry

Este artículo muestra cómo documentar eventos actuales desde una perspectiva arqueológica. Con un estudio de caso sobre la pandemia de COVID-19 en Noruega, ofrecemos herramientas asequibles para documentar amplios patrones de espacio y comportamiento que emergen a través de la cultura material. Destacando la importancia de la ética en el trabajo de temas contemporáneos, adaptamos los métodos de campo arqueológico que incluyen la geolocalización, la fotografía y el modelado tridimensional para establecer cambios en la materialidad que muestran los cambios en la socialidadhumana asociados con la pandemia. Al integrar datos de cuatro colaboradores, indicamos que este flujo de trabajo puede involucrar a un público más amplio como recolectores y colaboradores de datos antropológicos para analizar fenómenos sociales inesperados. Las perspectivas arqueológicas contemporáneas, llevadas en respuesta rápida, brindan interpretaciones alternativas sobre el desarrollo de los eventos actuales, que en este caso pueden quedar eclipsadas por la materialidad de la respuesta corporativa y estatal a gran escala.

Palabras clave: arqueología contemporánea, COVID-19, encuesta de arqueología, eventos actuales, fotogrametría

Archaeology is responsive to current events, from global migration and refugee crises (De León 2012, 2015; Hamilakis 2016; Kiddey 2019) to deforestation (González-Ruibal and Hernando 2010), pollution (Pétursdóttir 2020; Schofield et al. 2020), and natural disaster (Dawdy 2006, 2016). Archaeological analysis reveals novel perspectives on contemporary human behavior (see also Nativ and Lucas 2020), drawing attention to manifestations of global geopolitics and local ways of coping expressed through the material world.

Scholars of materiality have turned to social phenomena typified by rapidly emergent and quickly transformative sites or sets of behaviors. These assemblages may develop through protests like Occupy Wall Street (Simms and Riel-Salvatore 2016), the Women's March following Donald Trump's election (Black 2017), or the Black Lives Matter movement (for a call to recover its material culture, see National Museum of African American History and Culture et al. 2020). Many temporary, transient sites occur unexpectedly and end just as rapidly. They may be broadly or narrowly experienced, they may be repeated regularly, or they may be one-offs. They may leave no obvious material traces to speak of, or they may transform a landscape. Unlike scholars studying deeper time, contemporary archaeologists might attend, experience, and contribute to the formation of these sites and events.

The COVID-19 pandemic has been such a case, catastrophic in nature, unique in that it was (and, at the time of writing, is) being experienced globally. Responding quickly, archaeologists and museum curators recorded and reflected on the crisis through material culture. Museums large and small issued calls to collect physical and digital materials (Franz and Gudis 2020; Popescu

Advances in Archaeological Practice 9(4), 2021, pp. 379-386

Copyright (1) The Author(s), 2021. Published by Cambridge University Press on behalf of Society for American Archaeology. This is an Open Access article, distributed under the terms of the Greative Commons Attribution-NonCommercial-NoDerivatives licence (http:/l creativecommons.org/licenses/by-nc-nd/4.0/), which permits non-commercial re-use, distribution, and reproduction in any medium, provided the original work is unaltered and is properly cited. The written permission of Cambridge University Press must be obtained for commercial re-use or in order to create a derivative work.

DOI: 10.1017/aap.2021.24 
2020). Other archaeologists collaborated to construct digital platforms to document experiences of the pandemic. The Viral Archive, for example, was established to crowdsource contributor images on Twitter (@Viral_Archive). Whereas some initiated collection, others called attention to the ubiquitous plastics spreading across the landscape, addressing how archaeological perspectives might be deployed to shape policy surrounding the growing problem of pandemic waste (Schofield et al. 2020). The material implications of the virus spread beyond discarded masks and gloves. Others hinted at the agentive materiality of the virus and its power to aggravate social inequality (Khatchadourian 2020). Additional scholars reflected on the impacts of COVID-19 on archaeologists themselves (Olson 2021). The authors of this article contributed to the response, arguing for the importance of a rapid-response methodology (Magnani and Magnani 2020) in an effort to analyze the shifting materiality of the pandemic and its implications for how it is remembered (Magnani et al. 2022).

Archaeologists have demonstrated the value of rethinking these moments, whether ongoing or in their immediate aftermath. But how can scholars respond to rapidly occurring events in which they unexpectedly find themselves? Diverse studies employing equally variable approaches have emerged under the banner of contemporary archaeology, and a vibrant tradition of rapidresponse collecting has expanded in museums to link the remembrance of recent history and broader publics. This article presents a methodology that can be quickly and democratically deployed to record current events.

We present a workflow based on widely available technologies and open platforms to document and analyze rapidly emerging, unanticipated, and ephemeral events from an archaeological perspective. In each section, we highlight how we selected our methodology and how it evolved over the course of the project. Drawing on a case study from the recent COVID-19 pandemic as it manifested in Troms $\varnothing$, Norway, in the spring of 2020, we provide a scalable approach accessible to scholars and members of the public. The manuscript presents a detailed methodology, but our results are presented elsewhere (Magnani et al. 2022). Considering its potential for intervention in ongoing events, we promote reflexive techniques that are responsive to context-in this case, shaped by social distancing and responsibility to do no harm (see also Kiddey 2017). Our study suggests that the materials ultimately associated with the coronavirus may postdate the height of the pandemic, replacing or becoming more numerous than early local innovations meant to reduce the transmission of disease.

\section{STEP 1: PROJECT PREPLANNING}

When is it appropriate to conduct fieldwork surrounding current events, and how should that fieldwork be structured? Archaeological ethics are increasingly tailored to address responsibilities toward stakeholder communities (see, for example, Vitelli and Colwell-Chanthaphonh 2006), whereas contemporary archaeologists deal with equally challenging topics ranging from conflict archaeology (for a reflection on the ethics of the field, see Moshenska 2008) to human suffering experienced through migration (De León 2015). Arguments supporting contemporary archaeological work have often related to the elucidation of structural inequalities resulting from state policies on migration, refugee crises, or homelessness (e.g., De León 2015; Kiddey 2017, 2019), and a need to bear witness (see, for example, Hicks and Mallet 2019). We point further to the scholarship of Kiddey, whose collaboration with homeless communities emphasizes an "ethic of care" and attentiveness to the needs and careful representation of informants (Kiddey 2017). Such critical approaches may be a productive starting point for contemporary archaeological research.

Engaging with current events is difficult, but in many cases, material methods provide a valuable tool with which to record, process, and reflect on such topics. In seeking a critical and reflexive approach to an archaeology of COVID-19, we point to the work of Stacey Camp and colleagues, who thoughtfully reflect on their positionalities and privilege. Although they demonstrate that practicing archaeology during a crisis can be a form of coping itself (Camp 2020), they emphasize the importance of reflecting on and minimizing health and social risks (Angelo et al. 2021).

Regarding the treatment of current events, we look further to our colleagues handling material culture in museums under the auspices of rapid-response collecting. Curators have critically approached the collection of digital and physical materials associated with COVID-19 and other current events-in some cases, highlighting the need to maintain public engagement and respectfulness (Heal 2020) while reducing physical contact with materials and people (see, for instance, Science Museum Group 2020).

With these foundations in mind, to record breaking events, archaeologists must be prepared to respond quickly but reflexively. The behavioral shifts surrounding COVID-19 represent a significant rearrangement of human action and materiality that warrant careful archaeological attention. As involuntary participants in the events, our observations of the coronavirus in Tromsø, an island city in northern Norway (see Figure 1), took place between March 12, 2020, and April 2021. In this article, we focus on the refinement of our methodology, and we reflect on the first two months of the pandemic, from March to May 2020.

The novel coronavirus emerged in Hubei Province, China, in late 2019 and spread to global consciousness by early 2020 (see World Health Organization 2020). In Norway, the location of our study, there were almost 9,000 cases and 252 deaths by early July (Norwegian Institute of Public Health 2021). At the peak of the first wave of the pandemic, Norwegian residents were permitted to move freely within respective towns and regions (in compliance with travel restrictions) but were advised to keep distance from one another and limit gathering. Although restaurants and stores remained open, many establishments and institutions were ordered to close in early March, and a phased reopening began at the end of April. By July 2020, as cases continued to rise in many parts of the world, international travel to Norway was allowed from most European countries, and local transmission of the disease was low. This hiatus was short lived, and additional waves gripped the country through fall 2020 and winter 2021 (Norwegian Institute of Public Health 2021).

The materiality of COVID-19 transcends the locations and materials recorded in this article-inaccessible spaces associated with health care or vaccine production, for instance, would have been impossible to consider for such a study. Our analysis mapped and was impacted by our national infrastructures (Magnani and Magnani 2020) and our privilege as nonessential workers who 


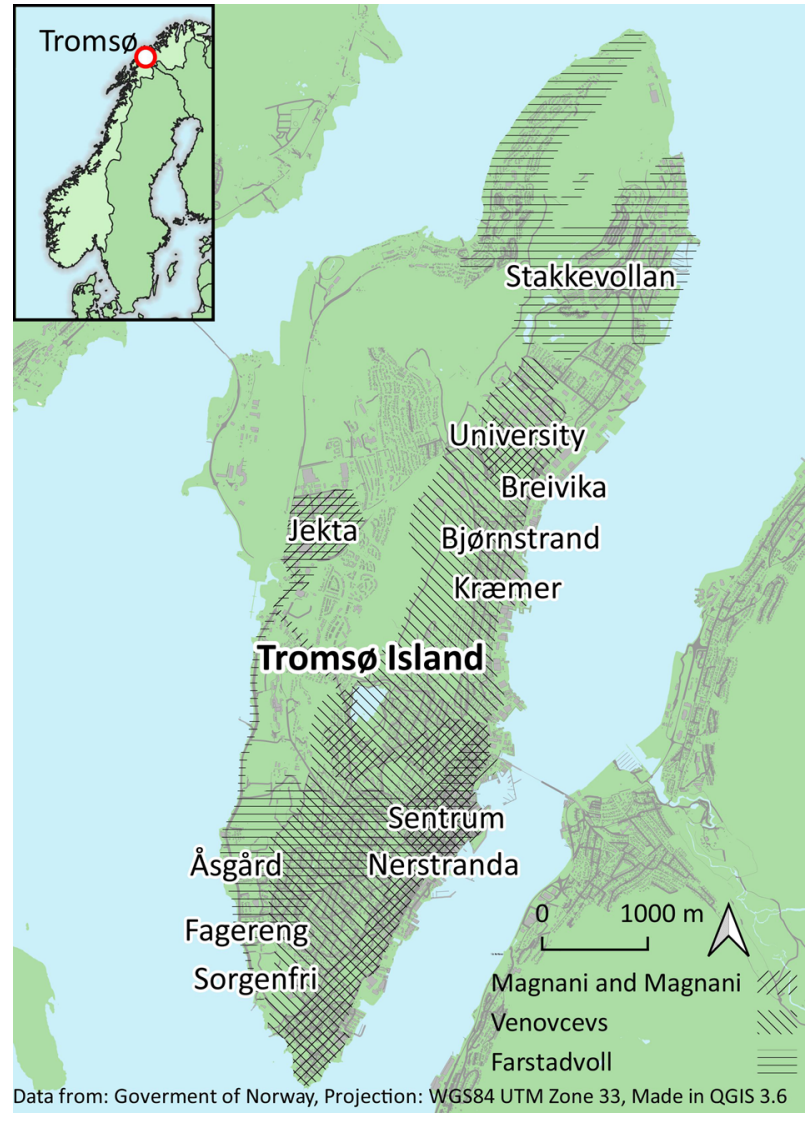

FIGURE 1. Map of the study area in northern Norway by Anatolijs Venovcevs, with each of the authors' regular ranges. Ranges were extrapolated from Google Timeline when available (Venovcevs) or from memory of each individual's regular movement through the city (Magnani, Magnani, and Farstadvoll).

could shift to working from home and dedicate time to data collection. Exceeding recommended social distancing guidelines in Norway, the primary data for this project consisted of photographs and observations of nonhuman subjects. Similarly, advisories were respected during outdoor data collection and survey. Further reducing unnecessary contact, all collaboration for the article was conducted remotely via Microsoft Teams and Zoom. In this way, the article sets out a methodology seeking responsible movement and (non)interaction adapted to local circumstances.

\section{STEP 2: DATA COLLECTION}

Following the identification of a contemporary event of interest, and a preliminary evaluation of the context at hand, archaeologists must tailor their data collection protocols. Although this project incorporated materials from four coauthors, the workflow is scalable and may be operationalized by one individual or used to collate crowdsourced data. Each scale provides its own benefits but will prompt new considerations. For instance, working as four coauthors, we could easily reflect on how we recorded data as a group. However, our survey area was relatively limited. Although larger crowdsourced datasets would introduce greater spatial coverage, they would also raise new considerations about ethics and data quality.

To respond quickly, our methodology relied entirely on materials we had on hand. The hardware and software requirements are minimal, based predominantly on smartphones, open-source platforms, and widely available programs. We acknowledge that this project was dependent on high-speed internet access and phone technology, which may limit the accessibility of our workflow in many localities. Stressing the highly contextual nature of data collection associated with recording current events, we report the development of our project chronologically, as it emerged over the course of a two-month period.

\section{Daily Routines}

Initially, the project researchers agreed that observations should be limited to our regular schedules-trips to stores, exercise, and other movement around the city-to avoid unnecessary social contact. None of us owned a vehicle, and public transportation was avoided and rarely utilized. Because we lived in three different locations, we frequented different areas of the city as part of our weekly routines (see again Figure 1). This provided coverage of changes over a majority of the island. We documented subjects of interest with our smartphones (including an iPhone 6, Huawei P30 Pro, and Samsung Galaxy S10e) as we encountered them, taking geolocated, time-stamped photographs. We photographed things, leaving people out of frame due to concerns over privacy. Each of us maintained a journal or log according to our individual preferences, which ultimately informed a final synthesis of our observations. For example, whereas one author primarily logged the pandemic through photos, another kept a detailed journal of observations on her phone's notepad. Finally, additional pictures were taken to generate three-dimensional models of some objects of interest (following modified protocols seen in Magnani et al. 2016).

\section{Consumption}

In light of international media coverage of overconsumption and hoarding, our first observations focused on local manifestations of shifting purchasing patterns in supermarkets. With no material response to speak of in the earliest days of the pandemic, our eyes were initially drawn to absences. We made inventories of missing products beginning on March 12, the morning before stockpiling began in Tromsø. Inventorying continued through our shopping trips into May 2020. In addition to shifting stocks, we made note of changing packaging (e.g., increased wrapping of bread products) and carrying devices (e.g., reduction in the number of baskets) implemented by vendors.

\section{Visual Representations of Social Distance}

As stores were restocked, the response to the pandemic increasingly included visual representations that structured the movement of people through the communication of social distancing guidelines and the closure of spaces. In the absence of interviewees, we came to focus on these signs as one of the most ubiquitous and visible testaments to the pandemic's impact across the city. Their presence and changes recorded local ways of coping as they intersected with national health measures in 
Norway. Signage and stickers distributed around the city were photographed as they were added, removed, or layered. We were attentive to public spaces and businesses that remained open, making note of visual representations encountered during our daily routines.

Parallel to our survey route (detailed below), we walked the streets of Troms $\varnothing$ 's downtown area to record signs visible to pedestrians. We focused on their materiality and content-for instance, were they hastily put up on printer paper, or did they evoke social solidarity through their language? Additionally, and following broader international trends, artistic representations incorporating rainbows proliferated throughout the pandemic. Rainbows dotted windows, and in particularly ephemeral instances, were etched in chalk along the seashore, on sides of buildings, or sidewalks.

\section{Surveying Discard}

During the first weeks of the pandemic, there was little movement outside of essential trips from our homes to supermarkets and exercise. After approximately one month, we felt comfortable conducting a set of systematic walks around the city following social distancing guidelines. Dovetailing with our daily observations, we conducted three comprehensive surveys of trash across Troms $\varnothing$ 's city center. A majority of waste deposited during the Norwegian winter was quickly encased in snow. Our first survey corresponded with a period of rapid snowmelt on April 8, 2020, which revealed a substantial quantity of materials dropped before and during the pandemic. Two additional surveys coincided with the loosening of national regulations in Norway, whereby schools and businesses reopened in phases. These took place on April 20 and April 29.

We used a GPS logger (Garmin GPSMAP 62sc) to document our tracks through the city, and we marked individual pieces of trash using a free smartphone geologging app named Mapit GIS, accurate to $4 \mathrm{~m}$. Recording tracks is also possible for free or inexpensively using a variety of GPS logging applications available on smartphones. We focused on downtown Tromsø because of its concentration of inhabitants and businesses, and its walkability. Compared to other areas of the island, the large pedestrian walkways and slow traffic made for an accessible survey environment. With three coauthors walking down each survey path, we were able to spot discarded materials across our route reliably.

We recorded artifacts that could clearly be attributed to before and during the coronavirus, and be linked to activities including commerce, socialization, and disease mitigation. We inferred approximate times of deposition, based on an object's origin and type (e.g., we would assume something came from before the pandemic if derived either from a business we knew to be closed at the time of our survey or from a behavior, such as clubbing, unlikely to be occurring illegally in Troms $\varnothing$ at the time). Along with GPS coordinates, we photographed artifacts to facilitate more detailed analysis in the future. Hotel keys, party glow sticks, and Burger King drink lids commingled with ubiquitous elements of personal protective equipment (PPE) such as gloves-and more rarely, hand sanitizer bottles or other antiseptic products-among receipts and shopping lists indicating purchase patterns and consumption (see Figure 2). Discarded face masks, relatively uncommon in Norway throughout the first wave of the pandemic, were absent from the systematic surveys reported in this article (although they became prominent in later waves as discussed in Magnani et al. 2022). Unidentifiable pieces of plastic or paper, candy wrappers, and tobacco products such as cigarette butts and snuff were left unmapped due to the time that would be required to plot them and their limited analytical value to our study.

\section{STEP 3: DATA SHARING AND VISUALIZATION}

Following data collection from individual and systematic surveys, it is necessary to share data with collaborators and visualize findings to support analysis and communication beyond the research team. Data were added to a shared online Google Drive folder, which was organized by author and location. Using metadata from their geotags, photographs were mapped, and a smaller subset of objects_including gloves, the first mask we encountered, and a painted rock-were selected for photogrammetric modeling to preserve their details and immediate contexts. We chose to model these objects because we considered them particularly salient markers of the coronavirus epidemic in Troms $\varnothing$ or internationally.

\section{Google Maps}

From the shared drive, photos were added to a master map that was accessible to the coauthors. First, geotagged information was extracted from the metadata of each photograph and copied into a separate spreadsheet containing the coordinates as well as image date and name. The spreadsheet was then imported into QGIS as a CSV file, converted into a KML file, and brought into Google My Maps_a free and accessible online platform for collaboratively creating, editing, and viewing geospatial information. Photos from the Google Drive were linked to their geolocations as viewable points on the map. This aided visualization during the writing of a larger research article, synthesizing changes over time and across space through the project. All static maps were made using QGIS 3.12, a free and open-source GIS software platform. Map layers were created for each of the surveys, allowing viewers to isolate photographs from either an individual coauthor or a specific survey date (e.g., April 8). Viewers can not only toggle through the survey dates and coauthors but also filter for categories, including gloves, disinfectant, grocery lists or receipts, and items from before the coronavirus.

\section{Three-Dimensional Visualization}

Whereas photographs provide two-dimensional documentation of the pandemic, we desired a more detailed record of some objects. Photogrammetry allows complex datasets to be collected with minimal expertise, cost, and time investment. The technique is increasingly used within and beyond academic contexts, from the scale of subcentimeter objects to landscapes (for reviews of the history and recent applications of the technique, see Magnani and Douglass 2018; Magnani et al. 2020). We decided to model a small subset of materials associated with the pandemic in Tromsø, which we expected to quickly degrade or be cleaned up. To be considered a candidate for a 3D model, the object had to be in a place away from traffic so as to allow us to move freely and safely around the subject. We selected a glove, mask, and painted rock to model using photogrammetry, recording both the objects and their immediate contexts (e.g., pavement, seashore, rocks) in high detail. 

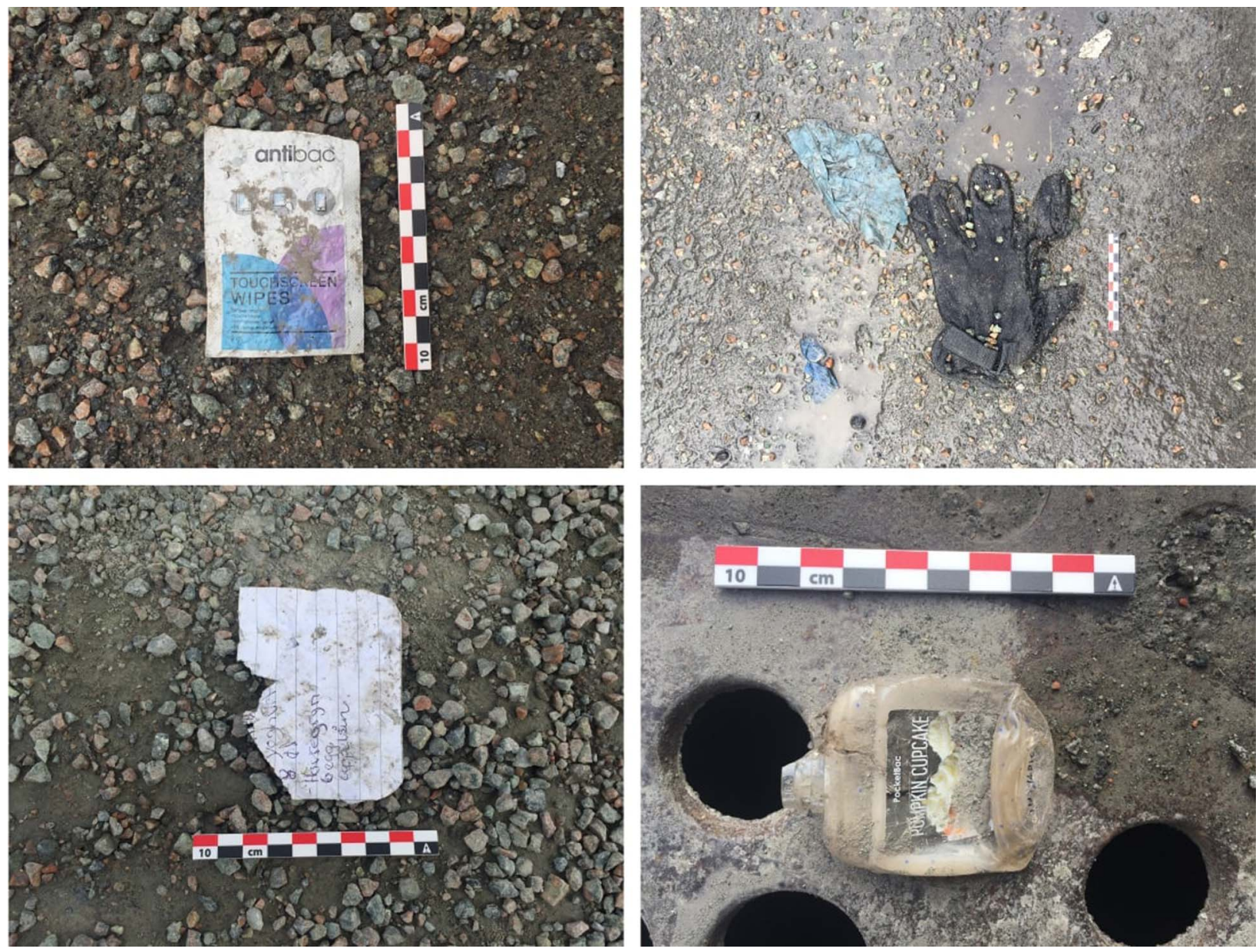

FIGURE 2. Sample of materials recorded during surveys of the downtown area photographed on April 20, 2020: (top left) antibacterial screen wipes; (top right) winter and protective gloves; (bottom left) shopping receipt; (bottom right) antibacterial hand sanitizer.

Using the camera phone on an iPhone 6, we moved around selected objects in a circle, varying camera height and angle. Between 27 and 47 photos were taken for each artifact (see Figure 3) and processed using Agisoft Metashape (for discussions on related expedient photogrammetric workflows, see Magnani et al. 2016, 2018 ). We acknowledge that Agisoft Metashape is not widely used by the broader public, although it has become standard in archaeological contexts. We point readers toward other open-source or low-cost alternatives available for devices from phones to computers on various operating systems (e.g., 3DF Zephyr Free, 3DS for Android OS, and Trnio for iOS).

\section{STEP 4: SYNTHESIZING RESULTS}

Finally, data may be analyzed to demonstrate how archaeological perspectives shed new light on current events. Here, we present the shifting materiality of social distancing recorded between March and May 2020. Through analysis of these transformations, we draw attention to localized behaviors as they layer with larger-scale national and corporate responses. Our results implicate materiality in the formation of memory surrounding the coronavirus in Tromsø. We anticipate that widely distributed state- and corporate-level representations will overshadow local ways of coping, which were less widely distributed and more highly variable.

Government action prompted changing social behaviors and, ultimately, new forms of innovative practices to mitigate the spread of the virus. A call to action by the Norwegian government on March 11 was followed by the required closure of educational centers, clubs, and barbers, among other establishments. On the night of the closures, supermarkets flooded with customers who began to hoard. The most panicked pandemic behaviors-that is, the rush and crowding of food suppliers-occurred in the absence of any posted health warnings or signs meant to structure responsible social distancing.

As supermarkets restocked and businesses closed, our focus shifted to the changing visual representations that indexed closure of spaces and encouraged social distance. In the days following an initial panic, quickly fashioned closure signs spread out across the city. The first, handwritten on printer paper, were visible as early as March 13. Many small businesses that served food exceeded health recommendations by closing, whereas others switched to providing takeout. 

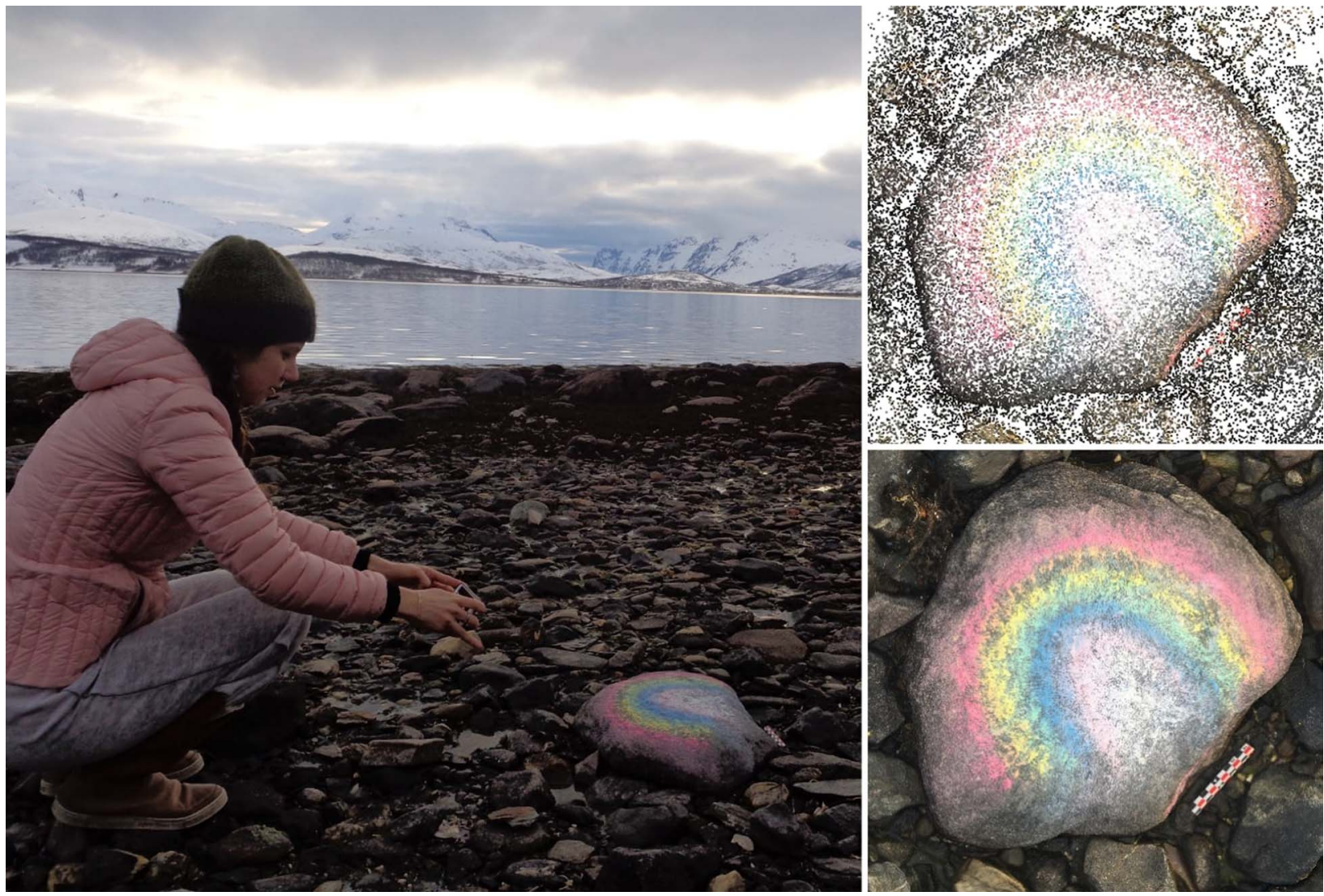

FIGURE 3. (left) Natalia Magnani collects data for a photogrammetric model of an ephemeral chalk representation on the southwest of the island; (right) images representing the workflow for photogrammetric modeling in Agisoft Metashape, from (top) sparse cloud generation to (bottom) generation of a textured model.

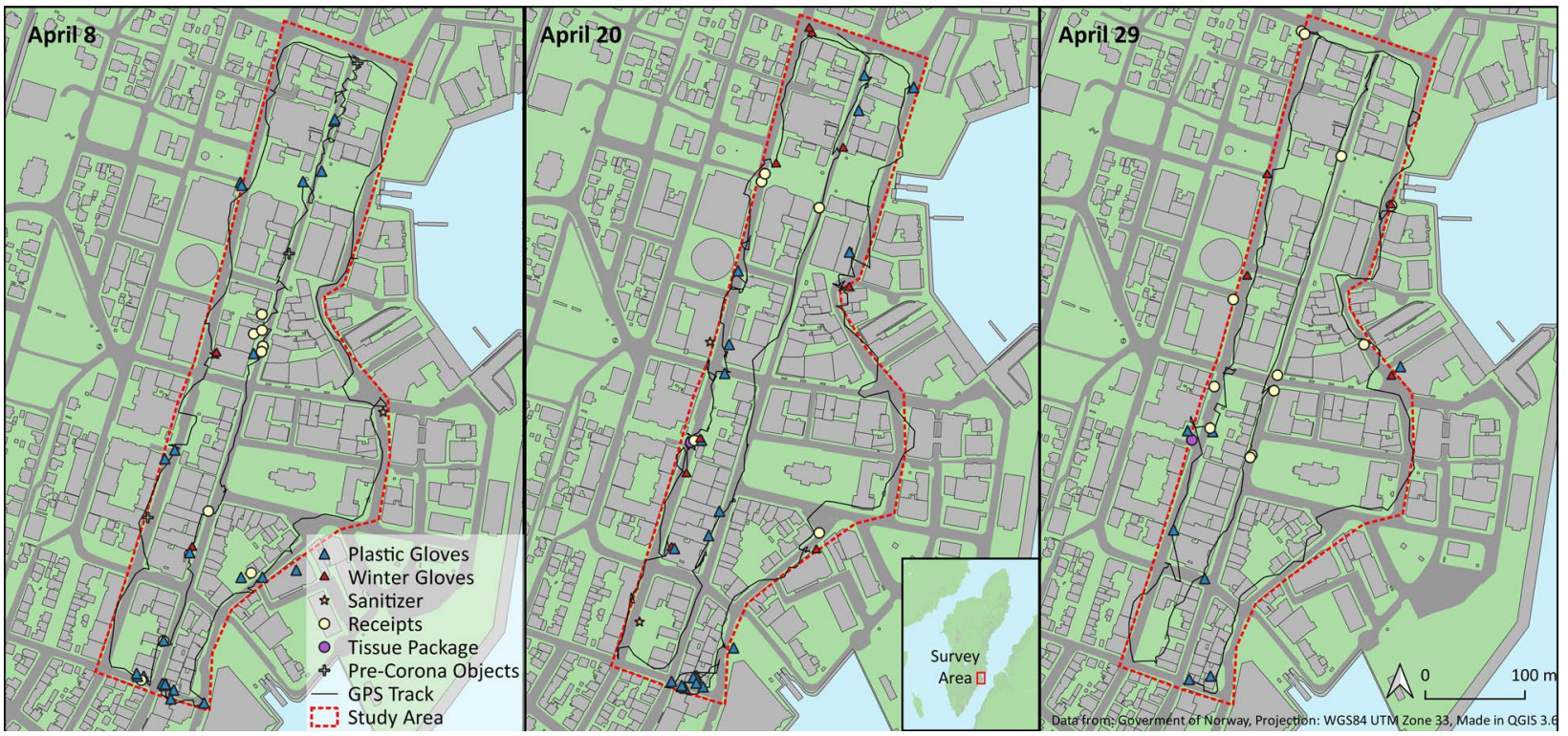

FIGURE 4. Distribution of discarded materials found during the three reported surveys. 
In spaces that remained open, quickly improvised solutions structured behavior to mitigate the transmission of the virus. Improvised barriers blocked off seating, and construction tape guided movements at registers and places where lines formed. As of late March, more subtle local variation also began to spread around the city. For example, bread slicing machines in some supermarkets were shut down. Shopping baskets were removed or unlocked to avoid unnecessary cleaning or contact. Some of these innovations remained at one store location, whereas others spread between locations over time.

By early April, when we began systematic pedestrian surveys of discarded waste, snowmelt revealed materials from before and during the pandemic. Our three surveys showed deviations from health advisories in unexpected directions (see Figure 4)-for instance, manifesting in the widespread use of gloves against the direct advice of the government or in the near-complete closure of nonessential businesses. The first survey occurred following a major spring thaw, evincing heavy usage of personal protective equipment such as gloves and lower quantities of antibacterial products such as hand sanitizer and wipes.

The most durable and ubiquitous markers of the pandemic manifested late in commercial spaces. Floor stickers encouraging patrons to keep their distance increasingly replaced temporary floor tape by mid-April. Official signs generated by centralized corporate and national authorities spread out through the city. By early May, an overwhelming flood of government-issued signs dotted the city's reopening businesses, filling the spaces of previously shuttered stores and locally devised closure signs. Meanwhile, the most common materials from the pandemicincluding discarded gloves and sanitization products-had been cleaned up or had begun to break down. The use of medical masks did not become prevalent until the second and third waves of the pandemic, nearly a year later. Because material culture influences the way events are remembered-that is, a common or durable object is more likely to circulate and evoke memories of these events in the future-the most ubiquitous state and corporate representations will likely have an impact on the pandemic's historicization in Norway.

\section{CONCLUSION}

In this article, we present a material-based methodology to record and analyze ephemeral events as they unfold. We simultaneously stress the ethical considerations that must underpin such studiesin this case, developing a practice based on social distancing. Material culture deployed late by state and corporate actors may overshadow local responses to the virus, and we suggest that memories of the pandemic may be impacted by these massproduced materials. Using an archaeological approach to study changes as they occur has the potential to shape how such moments are inscribed and remembered.

Our primary data were collected through daily routines, and our workflow was based on easily accessible technologies. Such protocols are practicable by not only academic archaeologists but also members of an interested public. Our approach allows for noninvasive yet interactive participation, which, in this case, also served to maintain social distance-a special requirement of this particular event. Although we combined data from four coauthors, the method is scalable to larger projects. Moving forward, it will be possible to expand this methodology and draw on crowdsourced data from a broader spectrum of stakeholders. Contemporary archaeology has the potential to contribute to a burgeoning citizen science that is emerging not only in archaeology (e.g., Seitsonen 2017) but also in other fields-for instance, in the biological sciences (e.g., Silvertown 2009) and the broader digital humanities.

Finally, our article presents a case study from Norway, where national response to the pandemic permitted relatively free movement within prescribed guidelines. Although variable regulations in other states would have structured our observations differently, we stress the adaptability of these methods to other research contexts for which a systematic understanding of spatial or temporal variation of contemporary material culture is beneficial. Such studies may shed light on diverse social phenomena as they unfold and may inform their memorialization. These analyses may impact not only how we remember but also how we prepare for similar moments or the continuation of the same crisis moving forward (see Kiddey [2017] for a discussion of archaeology's potential for collaborative social intervention and Schofield et al. [2021]). Considering Reid and colleagues' (1975) early suggestion that archaeology concerns the study of human-material interactions writ large, explicitly developing accessible approaches to elucidate these interactions promises new critical roles for archaeology in society.

\section{Acknowledgments}

The authors would like to thank the anonymous peer reviewers who improved this piece significantly through their critical commentary. Matthew Magnani would like to further acknowledge the Department of Anthropology at Harvard University, where he was based when starting this research.

\section{Data Availability Statement}

Data for this manuscript is available by request from the corresponding author.

\section{REFERENCES CITED}

Angelo, Dante, Kelly M. Britt, M. Lou Brown, and Stacey Camp

2021 Private Struggles in Public Spaces: Documenting COVID-19 Material

Culture and Landscapes. Journal of Contemporary Archaeology 8:154-184 Black, Shannon

2017 KNIT + RESIST: Placing the Pussyhat Project in the Context of Craft Activism. Gender, Place and Culture 24:696-710.

Camp, Stacey

2020 Coronavirus Disease 2019 (COVID-19) Heritage: Coping with Trauma by Documenting Trauma. Society for Historical Archaeology Newsletter 53(2):17-18.

Dawdy, Shannon Lee

2006 The Taphonomy of Disaster and the (Re)Formation of New Orleans. American Anthropologist 108:719-730.

2016 Patina: A Profane Archaeology. University of Chicago Press, Chicago. De León, Jason

2012 Better to Be Hot Than Caught: Excavating the Conflicting Roles of Migrant Material Culture. American Anthropologist 114:477-495.

2015 The Land of Open Graves: Living and Dying on the Migrant Trail. University of California Press, Oakland. 
Franz, Kathleen, and Catherine Gudis

2020 Documenting COVID-19. Journal of American History 107:692-695

González-Ruibal, Alfredo, and Almudena Hernando

2010 Genealogies of Destruction: An Archaeology of the Contemporary Past in the Amazon Forest. Archaeologies 6:5-28.

Hamilakis, Yannis

2016 Archaeologies of Forced and Undocumented Migration. Journal of Contemporary Archaeology 3:121-139.

Heal, Sharon

2020 Covid-19: The Ethics of Contemporary Collecting. Museums Association. Electronic document, https://niarchive.org/wp-content/uploads/2020/04/ Covid-19_-the-ethics-of-contemportary-collecting-_-Museums-Association. pdf, accessed September 28, 2021.

Hicks, Dan, and Sarah Mallet

2019 Lande: The Calais "Jungle" and Beyond. Policy Press, Bristol, United Kingdom.

Khatchadourian, Lori

2020 False Dilemmas? Or What COVID-19 Can Teach Us about Material Theory, Responsibility and "Hard Power." Antiquity 94:1649-1652.

Kiddey, Rachael

2017 Homeless Heritage: Collaborative Social Archaeology as Therapeutic Practice. Oxford University Press, Oxford.

2019 Reluctant Refuge: An Activist Archaeological Approach to Alternative Refugee Shelter in Athens (Greece). Journal of Refugee Studies 33:599-621.

Magnani, Matthew, and Matthew Douglass

2018 Photogrammetry and Stereophotogrammetry. In Encyclopedia of Archaeological Sciences, edited by Sandra L. López Varela. WileyBlackwell, Malden, Massachusetts. https://doi.org/10.1002/ 9781119188230.saseas0451, accessed September 22, 2021.

Magnani, Matthew, Matthew Douglass, and Samantha T. Porter

2016 Closing the Seams: Resolving Frequently Encountered Issues in Photogrammetric Modelling. Antiquity 90:1654-1669.

Magnani, Matthew, Matthew Douglass, Whittaker Schroder, Jonathan Reeves, and David R. Braun

2020 The Digital Revolution to Come: Photogrammetry in Archaeological Practice. American Anthropologist 85:737-760.

Magnani, Matthew, Anni Guttorm, and Natalia Magnani

2018 Three-Dimensional, Community-Based Heritage Management of Indigenous Museum Collections: Archaeological Ethnography, Revitalization and Repatriation at the Sámi Museum Siida. Journal of Cultural Heritage 31:162-169.

Magnani, Matthew, Natalia Magnani, Anatolijs Venovcevs, and Stein Farstadvoll 2022 A Contemporary Archaeology of Pandemic. Journal of Social Archaeology, in press.

Magnani, Natalia, and Matthew Magnani

2020 Material Methods for a Rapid-Response Anthropology. Social Anthropology 28:312-314

Moshenska, Gabriel

2008 Ethics and Ethical Critique in the Archaeology of Modern Conflict. Norwegian Archaeological Review 41:159-175.

National Museum of African American History and Culture, National Museum of American History, and Anacostia Community Museum

2020 Statement on Efforts to Collect Objects at Lafayette Square. https:// www.si.edu/newsdesk/releases/statement-efforts-collect-objects-lafayettesquare, accessed June 16, 2021

Nativ, Assaf, and Gavin Lucas

2020 Archaeology without Antiquity. Antiquity 94:852-863.

Norwegian Institute of Public Health

2021 Daily Report and Statistics about Coronavirus and COVID-19. Electronic document, https://www.fhi.no/en/id/infectious-diseases/coronavirus/dailyreports/daily-reports-COVID19/, accessed July 15, 2021

Olson, Kyle G.

2021 Disciplinary Futures and Reorienting Research: A Reply to Jobson and Rosenzweig on Doing Anthropology in the Age of COVID. American Anthropologist 123:170-175.

Pétursdóttir, Póra

2020 Anticipated Futures? Knowing the Heritage of Drift Matter. International Journal of Heritage Studies 26:87-103.

Popescu, Adam

2020 How Will We Remember the Pandemic? Museums Are Already Deciding. New York Times, May 25. https://www.nytimes.com/2020/05/25/ arts/design/museums-covid-19-collecting.html, accessed September 22, 2021.

Reid, Jefferson J., Michael B. Schiffer, and William L. Rathje

1975 Behavioral Archaeology: Four Strategies. American Anthropologist 77:864-869

Schofield, John, Estelle Praet, Kathy A. Townsend, and Joanna Vince 2021 "COVID Waste" and Social Media as Method: An Archaeology of Personal Protective Equipment and Its Contribution to Policy. Antiquity 95:435-449

Schofield, John, Kayleigh J. Wyles, Sean Doherty, Andy Donnelly, Jen Jones, and Adam Porter

2020 Object Narratives as a Methodology for Mitigating Marine Plastic Pollution: Multidisciplinary Investigations in Galápagos. Antiquity 94:228-244.

Science Museum Group

2020 Ethical Guidelines: Collecting Covid-19. Electronic document, https:// www.sciencemuseumgroup.org.uk/wp-content/uploads/2020/04/SMGEthical-guidelines-Covid-19.pdf, accessed June 22, 2021

Seitsonen, Oula

2017 Crowdsourcing Cultural Heritage: Public Participation and Conflict Legacy in Finland. Journal of Community Archaeology and Heritage 4:115-130

Silvertown, Jonathan

2009 A New Dawn for Citizen Science. Trends in Ecology and Evolution 24:467-471

Simms, Crystal R., and Julien Riel-Salvatore

2016 Occupy Archaeology! Towards an Activist Ethnoarcheaology of Occupy Denver. SAA Archaeological Record 16(3):33-42

Vitelli, Karen D., and Chip Colwell-Chanthaphonh

2006 Archaeological Ethics. 2nd ed. AltaMira Press, Lanham, Maryland.

World Health Organization

2020 Coronavirus Disease 2019 (COVID-19): Situation Report 1. Electronic document, https://www.who.int/docs/default-source/coronaviruse/ situation-reports/20200121-sitrep-1-2019-ncov.pdf?sfvrsn=20a99c10_4, accessed May 11, 2020

\section{AUTHOR INFORMATION}

Matthew Magnani (matthew.magnani@uit.no, corresponding author) and Natalia Magnani U UTT The Arctic University of Norway, Department of Social Sciences, Tromsø, Norway

Anatolijs Venovcevs and Stein Farstadvoll — UiT The Arctic University of Norway, Department of Archaeology, History, Religious Studies and Theology, Tromsø, Norway 